\title{
Piata palisadegrass deferred in the fall: effects of initial height and nitrogen in the sward structure
}

\author{
Braulio Maia de Lana Sousa ${ }^{1}$, Hélio Henrique Vilela ${ }^{1}$, Andreza Luzia Santos ${ }^{1}$, Manoel \\ Eduardo Rozalino Santos ${ }^{2}$, Domicio do Nascimento Júnior ${ }^{1}$, Camila Zimmer de Assis ${ }^{1}$, Bruno \\ Damaceno Faria ${ }^{1}$, Gabriel de Oliveira Rocha ${ }^{1}$
}

\footnotetext{
1 Universidade Federal de Viçosa, Departamento de Zootecnia, Viçosa, MG.

2 Universidade Federal de Uberlândia, Faculdade de Medicina Veterinária e Zootecnia, Uberlândia, MG.
}

\begin{abstract}
The objective of this study was to evaluate the mass of the forage and of the morphological components, and the sward structure in Piata palisadegrass (Brachiaria brizantha cv. Piata) deferred in function of different initial heights and nitrogen levels. Two levels of nitrogen (75 and $150 \mathrm{~kg} / \mathrm{ha}$ ) and one control without fertilization associated to three initial deferring heights $(20,30$, and $40 \mathrm{~cm}$ ) were evaluated. The design was of completely randomized blocks with three replications in a subdivided plot scheme. A raise in the initial deferment height and in the fertilization elevated the sward and extended tiller heights, the leaf area index, and the light interception by the sward. The piata palisadegrass deferred with an initial height of $40 \mathrm{~cm}$ presented a higher forage mass with lower percentage of leaf blades, and higher stem and dead tissue quantity. Additionally, this management strategy resulted in lower bulk density of leaf blade and in higher bulk densities of stems and dead tissue. The utilization of $150 \mathrm{~kg} / \mathrm{ha}$ of nitrogen raised the production and the bulk density of deferred piata palisadegrass forage and increased production and bulk density of leaves and stems. In the region of Viçosa, Minas Gerais, the piata palisadegrass deferred with an initial height of $30 \mathrm{~cm}$ and fertilized with $75 \mathrm{~kg} / \mathrm{ha}$ of nitrogen in the beginning of the fall presents adequate mass and structure to animal production in the winter.
\end{abstract}

Key Words: Brachiaria brizantha, ecophysiology, grassland management

\section{Introduction}

Deferment is the management strategy in which a certain area of the pasture is excluded from the grazing, aiming at the accumulation of forage during the period of plant growth, for future utilization at time of scarcity. For being a simple management strategy and of lower production cost, once the forage harvest is performed by the animal itself, it is considered of easy application at the management of pastures.

Deferred pastures are associated with the presence of elevated forage mass with low nutritive value. The advancement at maturity of forage plants results in higher quantity of reproductive and fallen tillers (Santos et al., 2009a) and dead tissues, whereas it causes increase in the neutral detergent fiber content and reduces the crude protein of the forage (Santos et al., 2009b). However, these observations must not be generalized, once adequate management considerations, such as time and period of deferment, forage species, initial height of the pasture, nitrogen level, among others, have commanding effect on the nutritive value and the structure of the deferred pasture (Fonseca \& Santos, 2009).
The sward structure and the management actions at the beginning of deferment can affect the quality of the deferred forage. It is known that nitrogen fertilization modifies the growth and development rates of the forage plant and, consequently, production of forage (Martuscello et al., 2005, 2006). Similarly, the initial height of the sward affects the foliage area, and hence, the interception of photosynthetically active radiation, which also determines the growth rate (Sousa et al., 2010, 2011) and forage production (Difante et al., 2009). Therefore, it is important to evaluate the effects of nitrogen fertilization and initial height of plants on the structural characteristics of the sward.

Several studies have been developed aiming at the investigation of the effects of management practices, such as duration of the deferment period, nitrogen fertilization and initial height of the sward on the structure of the deferred pasture on B. decumbens (Santos et al., 2009a,b). However, studies with deferred Piata Palisadegrass (B. brizantha cv. Piata) are scarce. Thus, this study was conducted to establish adequate criteria for the correct utilization of deferred Piata palisadegrass in the region of Viçosa - MG, by means of evaluation of forage mass and 
other descriptive characteristics of the structure of sward management with different initial heights and nitrogen levels.

\section{Material and Methods}

The experiment was performed in the period from March 20 to July 1st, 2010, in the Setor de Forragicultura of the Departamento de Zootecnia, at Universidade Federal de Viçosa (UFV), located in Viçosa, Minas Gerais. Approximate geographic coordinates of the experiment site are $20^{\circ} 45^{\prime}$ South latitude, $42^{\circ} 51^{\prime}$ West longitude and altitude of $651 \mathrm{~m}$. An area with Piata palisadegrass of approximately $250 \mathrm{~m}^{2}$ established in January, 2009 was utilized.

The climate of the region of Viçosa, according to the Köppen classification, is of Cwa type, with annual rainfall around $1,340 \mathrm{~mm}$ and mean relative air humidity of $80 \%$. The climatic data recorded during the experimental period were obtained at the meteorological station of the Departamento de Engenharia Agrícola of UFV, located at about 1,000 $\mathrm{m}$ from the experimental area (Table 1).

The soil was classified as Red-Yellow Argissoil of loam-clayey texture (EMBRAPA, 2006), and, according to the results of the chemical analysis, performed at the beginning of the experimental period, on the $0-20-\mathrm{cm}$ layer, it presented the following characteristics: $\mathrm{pH}$ in $\mathrm{H}_{2} \mathrm{O}$ : 5.50; P: 1.40 (Mehlich-1) and K: $36.00 \mathrm{mg} / \mathrm{dm}^{3} ; \mathrm{Ca}^{2+}$ : 2.10; $\mathrm{Mg}^{2+}: 0.70$ and $\mathrm{Al}^{3+}: 0.00 \mathrm{cmol}_{\mathrm{c}} / \mathrm{dm}^{3}(\mathrm{KCl} 1 \mathrm{~mol} / \mathrm{L})$. Based on these results, the liming was not done. At the beginning of the deferment period (3/20/2010), $50 \mathrm{~kg} / \mathrm{ha}$ $\mathrm{P}_{2} \mathrm{O}_{5}$ were applied in the form of single superphosphate, and $60 \mathrm{~kg} / \mathrm{ha} \mathrm{K}_{2} \mathrm{O}$, in the form of potassium chlorite.

Combinations between conditions of nitrogen fertilization, randomized to the plots $\left(27.6 \mathrm{~m}^{2}\right)$, and sward heights at the beginning of the deferment period, randomized on the subplots $\left(9.2 \mathrm{~m}^{2}\right)$ were evaluated. Nitrogen doses were 75 and $150 \mathrm{~kg} / \mathrm{ha}$ plus control without nitrogen; initial heights were 20,30 and $40 \mathrm{~cm}$. The design was completely randomized with three repetitions, in a subdivided-plots arrangement. The criterion utilized for the definition of the blocks was the variation of the relief of the experimental area.

The experimental area was subdivided with the aid of wood stakes, in nine plots. Each plot, in turn, was subdivided into three subplots of $9.2 \mathrm{~m}^{2}$ that, not considering the boundaries, had floor area of $5.0 \mathrm{~m}^{2}$.

The Piata palisadegrass remained deferred for 73 days, with the beginning of the fall and the end of deferment in the winter (3/20 to 7/1/2010). On the day of the start of the experiment, the Piata palisadegrass had about $50 \mathrm{~cm}$ average height and was lowered by means of mechanical cut for the respective heights assessed. On the initial deferment date, pre-programmed nitrogen doses were applied, in the form of ammonium sulphate. Because of the presence of sulfur in the ammonium sulphate, this nutrient was corrected in the plots which received different nitrogen doses, by means of powdered sulfur. Both were applied in a single dose, and at the end of the afternoon. After the fertilization, the area was watered to elevate soil moisture and reduce possible nitrogen losses by volatilization. On the last deferment day (7/1/2010), all the evaluations in Piata palisadegrass were performed.

The mensuration of light interception by the sward, from the leaf area index and the leaf angle in relation to the soil (leaves, stem and dead tissue) was performed by utilizing a Plant Canopy Analyzer LAI 2000 (LI-COR ${ }^{\circledR}$ ) in two random spots per experimental unit. In each spot, one reading above the sward and five on the soil surface were taken.

Measurements of sward and extended tiller height were performed on 10 spots per experimental unit. Sward height in each spot was determined by scale graduated in centimeters, and had the distance between the skyline of plants top and soil as criterion. Extended tiller height was measured by extending five tillers from the grass in the vertical direction and noting the longest distance from the soil to the tip of the leaves. The plant falling index, calculated by the quotient between the extended tiller height and sward height (Santos et al., 2009a), aimed at determining the degree of lodging verified in some deferred pastures.

For the determination of forage mass and morphological components, the cut of all tillers within a $0.16-\mathrm{m}^{2}$ square in

Table 1 - Monthly means of the minimum, average, and maximum daily temperatures, total monthly rainfall and total monthly evaporation from March to July in 2010

\begin{tabular}{|c|c|c|c|c|c|}
\hline Month & Average temperature $\left({ }^{\circ} \mathrm{C}\right)$ & Maximum temperature $\left({ }^{\circ} \mathrm{C}\right)$ & Minimum temperature $\left({ }^{\circ} \mathrm{C}\right)$ & Rainfall (mm) & Evaporation (mm) \\
\hline March & 22.9 & 29.2 & 19.1 & 184.8 & 121.7 \\
\hline April & 20.4 & 27.1 & 16.3 & 28.1 & 103.4 \\
\hline May & 18.4 & 24.9 & 14.3 & 35.4 & 76.0 \\
\hline June & 15.3 & 23.5 & 9.9 & 0.9 & 73.6 \\
\hline July & 17.3 & 25.0 & 12.4 & 0.0 & 84.9 \\
\hline
\end{tabular}


two areas representing the average condition of the sward in each experimental area was performed, close to the ground. Samples were conditioned in plastic bags, and weighted in the lab. From each sample, two subsamples were taken; one was weighted, conditioned in paper bag and sent to forced-ventilation oven for $72 \mathrm{~h}$, and the other was manually separated into green leaf blade, green stem and dead tissue. Inflorescence and green leaf sheath were incorporated into the green stem fraction. The part of the leaf blade that did not present senescence signs (green organ) was incorporated into the green leaf blade fraction. Parts of stems and senescent and dead leaf blades (with yellowing or necrotizing of the organ) were incorporated into the dead tissue fraction. After separation, the components were dried in forced-ventilation oven at $65^{\circ} \mathrm{C}$ for $72 \mathrm{~h}$, and then weighed.

The bulk density of the forage and morphological components, expressed in $\mathrm{kg} / \mathrm{ha}$.cm was calculated by the division of the masses of forage and their morphological components by the sward height, respectively.

All the evaluation procedures were done on the last day of deferment (7/1/2010), with data analyses performed through the software SAEG (Sistema para Análises Estatísticas, version 8.1.) For each characteristic, comparison was made between the marginal means of the primary (nitrogen dose) or secondary (initial height of deferment) factor levels. When the interaction between the factors was significant, comparison of the levels of a factor separately for each level of the other factor was made. The means of the factors were compared by the Tukey test at a significance level of $5 \%$ probability of type I error.

\section{Results and Discussion}

There was interaction $(\mathrm{P}<0.05)$ between the initial deferment height and the nitrogen dose for the heights of the sward and extended tiller, leaf area index and light interception. Overall, these were lower in the Piata palisadegrass deferred without nitrogen fertilization, intermediary in those fertilized with $75 \mathrm{~kg} / \mathrm{ha}$ of nitrogen and higher in those fertilized with $150 \mathrm{~kg} / \mathrm{ha}$ of nitrogen (Table 2). The elevation at the initial deferment height, when the Piata palisadegrass was deferred without nitrogen and with $75 \mathrm{~kg} / \mathrm{ha}$ of nitrogen, resulted in increase in the heights of the sward and extended tiller and light interception. Piata palisadegrass deferred with greater initial heights and fertilized with $75 \mathrm{~kg} / \mathrm{ha}$ of nitrogen presented even higher foliage area index (Table 2). The change in the initial deferment height did not alter sward
Table 2 - Sward and extended tiller heights, leaf area índex, and ligth interception of Piata palisadegrass deferred with initial height and nitrogen doses

\begin{tabular}{|c|c|c|c|}
\hline \multirow{2}{*}{$\begin{array}{l}\text { Initial defermer } \\
\text { height }(\mathrm{cm})\end{array}$} & \multicolumn{3}{|c|}{ Nitrogen level (kg/ha) } \\
\hline & Control & 75 & 150 \\
\hline & \multicolumn{3}{|c|}{ Sward heigth $(\mathrm{cm})$} \\
\hline 20 & 25.5Сс (1.88) & 49.9Cb (4.19) & 76.4Aa (2.87) \\
\hline 30 & $44.6 \mathrm{Bc}(1.32)$ & $61.2 \mathrm{Bb}(9.04)$ & 77.6Аа (3.41) \\
\hline \multirow[t]{2}{*}{40} & $54.7 \mathrm{Ab}(1.71)$ & 76.3Аа $(0.91)$ & 79.3Аа $(1.42)$ \\
\hline & \multicolumn{3}{|c|}{ Extended tiller height $(\mathrm{cm})$} \\
\hline 20 & 28.9Bс (1.96) & $53.8 \mathrm{Bb}(4.34)$ & 89.0Аа (4.59) \\
\hline 30 & $48.2 \mathrm{Ac}(0.68)$ & $66.5 \mathrm{Bb}(10.58)$ & 89.6Аа (6.27) \\
\hline \multirow[t]{2}{*}{40} & $60.9 \mathrm{Ab}(1.63)$ & 83.2Аа (1.19) & 91.6Аa $(4.02)$ \\
\hline & \multicolumn{3}{|c|}{ Leaf area index } \\
\hline 20 & 2.1Ac $(5.00)$ & $5.0 \mathrm{Bb}(1.10)$ & 7.6Аa $(0.10)$ \\
\hline 30 & 2.8Ac $(1.50)$ & $5.7 \mathrm{Bb}(1.00)$ & 8.1Аa $(0.10)$ \\
\hline \multirow[t]{2}{*}{40} & $3.0 \mathrm{Ab}(1.20)$ & 7.5Аа $(0.10)$ & 8.2Аа $(0.10)$ \\
\hline & \multicolumn{3}{|c|}{ Ligth interception (\%) } \\
\hline 20 & $79.3 \mathrm{Bc}(0.35)$ & $97.5 \mathrm{Bb}(0.50)$ & 99.7Аа $(0.12)$ \\
\hline 30 & 89.4Ac $(0.18)$ & $98.2 \mathrm{Bb}(0.91)$ & 99.8Аа $(0.45)$ \\
\hline 40 & $90.6 \mathrm{Ab}(0.13)$ & 99.7Аa $(0.42)$ & 99.8Aa $(0.07)$ \\
\hline
\end{tabular}

For each characteristic, means followed by the same uppercase letter in the column and lowercase letter in the row do not differ $(\mathrm{P}>0.05)$ by the Tukey test. Numbers inside parentheses correspond to the standard error of the mean.

and extended tiller heights, leaf area index or light interception when the Piata palisadegrass was deferred with $150 \mathrm{~kg} / \mathrm{ha}$ of nitrogen (Table 2). These results occurred because the elevation at the initial deferment height results in greater foliage area at the beginning of regrowth (Sousa et al., 2010, 2011) and, consequently, in higher photosynthetic capacity of plants (Parsons, 1988), which increase the growth and green leaf blade development rates of the sward. Nitrogen, in turn, increases the number of living cells under division and stimulates cell lengthening (Schnyder et al., 2000), accelerating the growth and green leaf blade development rates of plants (Martuscello et al., 2005, 2006).

The absence of nitrogen fertilization generated a sward structure with lower leaf area index (Table 2) and bigger leaf angle (49, 45 and $34^{\circ}$ for the doses of 0,75 and $15 \mathrm{~kg} / \mathrm{ha}$ of nitrogen, respectively), determining lower light interception by the sward. Plants with bigger leaf angle presented a more upright pattern, and, thus, intercept smaller amount of light with the same leaf area when compared with plants with a more horizontal pattern (lower leaf angle).

Contrarily, all the possible combinations between the doses of 75 and $150 \mathrm{~kg} /$ ha of nitrogen with the initial heights of 20, 30 and $40 \mathrm{~cm}$ resulted in light interception values higher than 95\%. Above 95\% light interception, the accumulation of forage is also reduced, once there is decrease in the percentage of leaves and increase in the amount of 
stems and dead tissues, which creates a structure unsuitable for the forage intake by animals (Trindade et al., 2007).

However, the use of the management criterion based on the interception of $95 \%$ of the light has not been used in the management of deferred pasture, once it is necessary to guarantee enough forage accumulation for the use during the time of scarcity (Fonseca \& Santos, 2009). The light interception in deferred pastures is, almost always, higher than 95\%. This fact makes the pasture deferment be associated with the elevated amount of forage, although of low quality. The elevated amount of forage associated with animal supplementation by means of protein salts, multiple mixtures or energy-protein supplements depending on the productive system (Reis et al., 2009) would result in better animal performance during the time of forage shortage. However, Santos et al. (2009c), evaluating deferred pastures of B. decumbens for 73, 103, 131 and 163 days, verified that high forage mass may not result in better animal performance, even utilizing supplementation. According to the authors, longer deferment periods would result in higher forage masses, although with lower amount of leaves and bigger amount of stems and dead tissues. In the situation mentioned, there was also more tiller falling, and the pasture presented reduced contents of crude protein and potentially digestible dry matter, in spite of high percentages of neutral detergent fiber. This response pattern affected negatively the performance of the cattle at the post-weaning phase, which expressed average daily gain of $0.692 ; 0.518 ; 0.390$ and $0.445 \mathrm{~kg} / \mathrm{animal}$.day when kept on the deferred pastures for 73, 103, 131 and 163 days, respectively. These results reveal that the structure of the deferred pasture is as important for the animal performance as the amount of forage. Thus, even if the purpose of the deferment is the accumulation of forage for the off season, it is not pertinent to extend the deferment period too much, avoiding the excessive maturation of the forage plant, and, consequently, providing better structure of the deferred pasture (Fonseca \& Santos, 2009).
The falling index (Santos et al., 2009a) allows analyzing better the effect of variation in sward and extended tiller heights on the lodging degree of plants. This variable was not affected $(\mathrm{P}>0.05)$ by the initial deferment height or nitrogen levels, presenting mean values of 1.10 and 1.13, respectively. This result contrasts those obtained by Santos et al. (2009a) on deferred pastures of B. decumbens, where they found higher sward lodging as the nitrogen level increased. However, the Piata palisadegrass has more rigid and less flexible stem, when compared with $B$. decumbens. This is the reason why, even with increase in sward and extended tiller heights, the falling index did not change. Moreover, it is possible that the deferment period to which the Piata palisadegrass was subjected (73 days) also contributed to the absence of plant falling.

The masses of forage and morphological components was affected $(\mathrm{P}<0.05)$ by the initial deferment height. The initial height of $40 \mathrm{~cm}$ resulted in greater forage mass, followed by the $30-\mathrm{cm}$ height, and lastly by the 20 -cm height (Table 3). The elevation in sward height results in greater foliage area at the beginning of regrowth (Sousa et al., 2010, 2011) and, consequently, higher photosynthetic capacity, increasing the speed of regrowth. Logically, as the deferment duration was the same the higher speed of regrowth determined elevation in forage mass.

Although it increases forage mass, the use of initial height at the deferment above $20 \mathrm{~cm}$ reduced the percentage of leaf blades and increased the amount of stems and dead tissues (Table 3). It is worth remarking that the Piata palisadegrass deferred with higher nitrogen doses presented, in the winter, light interception above 95\% (Table 2). This indicates that the intraspecific competition for light was fierce (Da Silva \& Nascimento Júnior, 2007). In this condition, the accumulation of leaf blades decreases, while the lengthening of stems increases (Barbosa et al., 2007; Da Silva et al., 2009) as a way to allocate the newest leaves to the top of the sward. This greater competition for

Table 3 - Structural characteristics of Piata palisadegrass deferred with three initial heights

\begin{tabular}{|c|c|c|c|}
\hline Characteristics & \multicolumn{3}{|c|}{ Initial deferment height $(\mathrm{cm})$} \\
\hline Forage mass (kg/ha of DM) & 6,112c (954.9) & 7,482b (850.8) & 9,060a $(787.8)$ \\
\hline Green stem (kg/ha of DM) & $27.3 b(3.69)$ & $34.1 \mathrm{ab}(2.69)$ & $40.3 a(3.10)$ \\
\hline Dead tissue (kg/ha of DM) & $23.8 b(6.63)$ & $34.2 \mathrm{a}(4.76)$ & $32.3 a(4.43)$ \\
\hline Bulk density of leaf blades (kg/ha.cm of DM) & $57.8 \mathrm{a}(4.11)$ & $38.8 b(3.98)$ & $35.6 b(3.17)$ \\
\hline
\end{tabular}

Means followed by the same letter in the rows do not differ $(\mathrm{P}>0.05)$ by Tukey test.

Numbers inside parentheses correspond to the standard error of the mean. 
light generates even more shading on the lower part of the sward, increasing senescence and death of young leaf blades and tillers (Lemaire, 2001).

The initial deferment heights did not bring differences $(\mathrm{P}>0.05)$ at the bulk density of the forage, which was, on average, $123.2 \mathrm{~kg} / \mathrm{ha} . \mathrm{cm}$. However, the bulk densities of leaf blades, stems and dead tissue were affected $(\mathrm{P}<0.05)$ by the initial deferment heights. The Piata palisadegrass deferred with initial heights with 30 and $40 \mathrm{~cm}$ presented lower bulk density of leaf blade and greater bulk densities of stems and dead tissues (Table 3).

The lower percentage and bulk density of leaf blades indicate that the Piata palisadegrass deferred with initial heights of 30 and $40 \mathrm{~cm}$ yields forage of lower qualities, once the leaf is the morphological component of the plant that has best nutritive value (Van Soest, 1994) and that the maximum intake occurs when the animals are in pastures with high density of accessible leaves (Euclides et al., 1999). Furthermore, the ingestive behavior of animals is sentient to variations in the structure of the forage sward (Palhano et al., 2007). Therefore, the bigger presence of stems may restrict forage intake, for being a physical barrier to defoliation, reducing the ease of harvesting by the grazing animal (Carvalho et al., 2005). In order to avoid these negative effects on the forage quality and on the structure as the initial height of the sward is elevated, the possibility of retarding the beginning of the deferment is regarded. Thus, one can obtain qualitative and quantitatively similar forage production, by adopting the production scheduling by means of deferment in different times and periods (Fonseca \& Santos, 2009), since the environmental conditions (photoperiod, temperature, soil moisture) are not too limiting to plant growth.

The masses of forage and morphological components were also affected $(\mathrm{P}<0.05)$ by nitrogen levels. Greater forage production was obtained on the Piata palisadegrass fertilized with $150 \mathrm{~kg} / \mathrm{ha}$ of nitrogen, intermediate production on that soil fertilized with $75 \mathrm{~kg} / \mathrm{ha}$ of nitrogen and lower on that with absence of nitrogen (Table 4). Nitrogen stimulates division and lengthening of the cell (Schnyder et al., 2000), accelerating plant growth and development rates, increasing the accumulation of forage and affecting the sward structure (Duru \& Ducrocq, 2000; Gastal et al., 1992). The Piata palisadegrass deferred with absence of nitrogen fertilization presented lower amount of leaves and stems and bigger amount of dead tissue. On the other hand, the utilization of $150 \mathrm{~kg} / \mathrm{ha}$ of nitrogen raised the production of leaves and stems and reduced the percentage of dead tissue (Table 4).

The bulk density of the forage and its components was also affected $(\mathrm{P}<0.05)$ by nitrogen fertilization. The bulk density was higher at the deferred Piata palisadegrass with $150 \mathrm{~kg} / \mathrm{ha}$ of nitrogen (Table 4), indeed as a reaction to the acceleration in the growth pace of plants by the use o nitrogen (Pereira et al., 2010). The utilization of $150 \mathrm{~kg} / \mathrm{ha}$ of nitrogen resulted, yet, in greater bulk densities of leaves and stems and smaller densities of dead tissues. The absence o nitrogen, in turn, generated a sward structure with lower bulk density of leaves and stems and higher density of teat tissue (Table 4).

In fact, the utilization of nitrogen increases forage mass (Table 4). However, the utilization of $150 \mathrm{~kg} / \mathrm{ha}$ of nitrogen resulted in greater mass and bulk density of stems. As discussed previously, the greater production of stems may limit the forage intake because of the lower nutritive value and physical constraints to the performance of the bite (Carvalho et al., 2005). Similarly to what was suggested for deferment heights, the possibility of reduction in the deferment period is considered when high doses of nitrogen are used, as a way to take advantage of the greater growth of plants, without compromising the sward structure or the forage quality. Logically, the environmental

Table 4 - Structural characteristics of Piata palisadegrass deferred with three nitrogen doses

\begin{tabular}{|c|c|c|c|}
\hline \multirow[t]{2}{*}{ Characteristics } & \multicolumn{3}{|c|}{ Nitrogen dose (kg/ha) } \\
\hline & Control & 75 & 150 \\
\hline Forage mass (kg/ha of DM) & 4,891c (535.09) & 7,317b (593.98) & $10,445 \mathrm{a}(472.42)$ \\
\hline Green leaf blade (kg/ha of DM) & 26.9b (2.59) & $39.7 a(3.73)$ & 41.5a (4.42) \\
\hline Green stem (kg/ha of DM) & $26.3 \mathrm{c}(3.92)$ & 34.5b (2.70) & 40.8a (2.31) \\
\hline Dead tissue (kg/ha of DM) & 46.8a (3.55) & 25.8b (3.33) & 17.7c (3.71) \\
\hline Bulk density of leaf blades (kg/ha.cm of DM) & $117.7 \mathrm{~b}(3.29)$ & $117.5 b(3.67)$ & 134.6a (6.39) \\
\hline Bulk density of green stem (kg/ha.cm of DM) & $31.5 c(3.06)$ & $46.6 \mathrm{~b}(4.49)$ & $54.1 \mathrm{a}(4.02)$ \\
\hline Bulk density of dead tissue (kg/ha.cm of DM) & 31.0b (4.96) & 40.5b (3.44) & $55.7 \mathrm{a}(5.36)$ \\
\hline Forage mass $(\mathrm{kg} / \mathrm{ha}$ of $\mathrm{DM})$ & $55.1 \mathrm{a}(4.57)$ & $30.4 \mathrm{~b}(4.11)$ & $24.8 \mathrm{~b}(5.53)$ \\
\hline
\end{tabular}

Means followed by the same letter in the rows did not differ $(\mathrm{P}>0.05)$ by Tukey test.

Numbers inside parentheses correspond to the standard error of the mean. 
conditions at the moment of deferment can be too limiting to pasture growth.

Contrarily, the absence of nitrogen fertilization reduced the population of leaves and the bulk density of leaves, and increased production and bulk density of dead tissue, which can also negatively affect forage intake. The results confirm the importance of nitrogen fertilization, not only to increase pasture production, but also as a way to replace the nutrients of the soil, keeping the sustainability of the productive system.

\section{Conclusions}

The initial sward height and the nitrogen dose modify the structural characteristics of the deferred pasture of Piata palisadegrass. Piata palisadegrass deferred in midMarch with initial height of $30 \mathrm{~cm}$ and fertilized with $75 \mathrm{~kg} / \mathrm{ha}$ of nitrogen presents adequate structure after the deferment.

\section{References}

BARBOSA, R.A.; NASCIMENTO JÚNIOR, D.; EUCLIDES, V.B.P. et al. Capim-tanzânia submetido a combinações entre intensidade e frequência de pastejo. Pesquisa Agropecuária Brasileira, v.42, n.3, p.329-340, 2007.

CARVALHO, P.C.F.; GENRO, T.C.M.; GONÇALVES, E.N. et al. Estrutura do pasto como conceito de manejo: reflexos sobre consumo e a produtividade. In: SIMPÓSIO SOBRE VOLUMOSOS NA PRODUÇÃO DE RUMINANTES, 2., 2005, Jaboticabal. Anais... Jaboticabal: FUNEP, 2005. p.107-124.

DA SILVA, S.C.; BUENO, A.A.O.; CARNEVALLI, R.A. et al. Sward structural characteristics and herbage accumulation of Panicum maximum cv. Mombaça subjected to rotational stocking managements. Scientia Agricola, v.66, n.1, p.8-19, 2009.

DA SILVA, S.C.; NASCIMENTO JÚNIOR, D. Avanços na pesquisa com plantas forrageiras tropicais em pastagens: características morfofisiológicas e manejo do pastejo. Revista Brasileira de Zootecnia, v.36, n.4, p.121-138, 2007 (supl. especial).

DIFANTE, G.S.; NASCIMENTO JÚNIOR, D.; EUCLIDES, V.P.B. et al. Sward structure and nutritive value of Tanzania guineagrass subjected to rotational stocking managements. Revista Brasileira de Zootecnia, v.38, n.1, p.9-19, 2009.

DURU, M.; DUCROCQ, H. Growth and senescence of the successive grass leaves o a tiller ontogenic development and effect of temperature. Annals of Botany, v.85, p.635-643, 2000.

EMPRESA BRASILEIRA DE PESQUISA AGROPECUÁRIA EMBRAPA. Serviço Nacional de Levantamento e Conservação de Solos. Sistema brasileiro de classificação de solos. 2.ed. Rio de Janeiro: Embrapa Solos, 2006. 306p.

EUCLIDES, V.P.B.; THIAGO, L.R.S.; MACEDO, M.C.M. Consumo voluntário de forragem de três cultivares de Panicum maximum sob pastejo. Revista Brasileira de Zootecnia, v.28, n.6, p.1177-1185, 1999.

FONSECA, D.M.; SANTOS, M.E.R. Diferimento de pastagens: Estratégias e ações de manejo. In: SIMPÓSIO DE FORRAGICULTURA E PASTAGEM, 6.; CONGRESSO DE
FORRAGICULTURA E PASTAGEM, 3., 2009, Lavras. Anais... Lavras: UFLA, 2009. p.65-88.

GASTAL, F.; BELANGER, G.; LEMAIRE, G. A model of the leaf extension rate of tall fescue in response to nitrogen and temperatute. Annals of Botany, v.70, p.437-442, 1992.

LEMAIRE, G. Ecophisiology of grasslands: dynamic aspects of forage plant populations in grazed swards. In: INTERNATIONAL GRASSLAND CONGRESS, 19., 2001, São Pedro. Proceedings... São Pedro: Fundação de Estudos Agrários Luiz de Queiroz, 2001. p.29-37.

MARTUSCELLO, J.A.; FONSECA, D.M.; NASCIMENTO JÚNIOR, D. et al. Características morfogênicas e estruturais do capim-xaraés submetido à adubação nitrogenada e desfolha. Revista Brasileira de Zootecnia, v.34, n.5, p.1475-1482, 2005.

MARTUSCELLO, J.A.; FONSECA, D.M.; NASCIMENTO JÚNIOR, D. et al. Características morfogênicas e estruturais do capim-massai submetido à adubação nitrogenada e desfolhação. Revista Brasileira de Zootecnia, v.35, n.3, p.665-672, 2006.

PALHANO, A.L.; CARVALHO, P.C.F.; DITTRICH, J.R. et al. Características do processo de ingestão de forragem por novilhas holandesas em pastagens de capim-mombaça. Revista Brasileira de Zootecnia, v.36, n.4, p.1014-1021, 2007.

PARSONS, A.J. The effects of season and management on the growth of grass swards. In: JONES, M.B.; LAZENBY, A. (Eds.) The grass crop: the physiological basis of production. London: Chapman \& Hall, p.129-177, 1988.

PEREIRA, L.E.T.; PAIVA, A.J.; DA SILVA, S.C. et al. Sward structure of Marandu palisadegrass subjected to continuous stocking and nitrogen-induced rhythms of growth. Scientia Agricola, v.67, n.5, p.531-539, 2010.

REIS, R.A.; RUGGIERI, A.C.; CASAGRANDE, D.R. et al. Suplementação da dieta de bovinos de corte como estratégia do manejo da pastagem. Revista Brasileira de Zootecnia, v.38, p.147-159, 2009 (supl. especial).

SANTOS, M.E.R.; FONSECA, D.M.; EUCLIDES, V.P.B. et al. Características estruturais e índice de tombamento de Brachiaria decumbens cv. Basilisk em pastagens diferidas. Revista Brasileira de Zootecnia, v.38, n.4, p.626-634, 2009a.

SANTOS, M.E.R.; FONSECA, D.M.; EUCLIDES, V.P.B. et al. Produção de bovinos em pastagens de capim-braquiária diferidas. Revista Brasileira de Zootecnia, v.38, n.4, p.635-642, 2009c.

SANTOS, M.E.R.; FONSECA, D.M.; BALBINO, E.M. et al. Capimbraquiária diferido e adubado com nitrogênio: produção e características da forragem. Revista Brasileira de Zootecnia, v.38, n.4, p.650-656, 2009b.

SCHNYDER, R.H.; SCHÄUFELE, R.; VISSER, R. et al. An integrated view of $\mathrm{c}$ and $\mathrm{n}$ uses in leaf growth zones of defoliated grasses. In: LEMAIRE, G.; HODGSON, J.; MORAES, A. et al. (Eds.) Grassland ecophysiology and grazing ecology. Wallingford: CAB International, 2000. p.41-60.

SOUSA, B.M.L; NASCIMENTO JUNIOR, D.; DA SILVA, S.C. et al. Morphogenetic and structural characteristics of Andropogon grass submitted to different cutting heights. Revista Brasileira de Zootecnia, v.39, n.10, p.2141-2147, 2010.

SOUSA, B.M.L.; NASCIMENTO JÚNIOR, D.; DA SILVA, S.C. et al Morphogenetic and structural characteristics of Xaraes palisadegrass submitted to cutting heights. Revista Brasileira de Zootecnia, v.40, n.1, p.53-59, 2011.

TRINDADE, J.K.; DA SILVA, S.C.; SOUZA JÚNIOR, S.J. et al. Composição morfológica da forragem consumida por bovinos de corte durante o rebaixamento do capim-marandu submetido a estratégias de pastejo rotativo Pesquisa Agropecuária Brasileira, v.42, n.6, p.883-890, 2007.

VAN SOEST, P.J. Nutritional ecology of the ruminant. 2.ed. New York: Cornell University Press, 1994. 476p. 